\title{
Japan and India: soft balancing as a reaction to China's rise?
}

\author{
Japão e Índia: soft balancing como uma reação \\ à ascensão da China?
}

http://dx.doi.org/10.1590/0034-7329201400205

WELLINGTON AMORIM*
ANTONIO HENRIQUE LUCENA DA SILVA**

Rev. Bras. Polít. Int. 57 (special edition): 73-90 [2014]

\section{Introduction}

Asia is becoming the most dynamic economic region in the world and also faces important changes in military power. Especially due to recent Chinese rise in economic and military terms, countries of Asia-Pacific region are constantly aware about Chinese movements. Japan and India, which are the largest economies in the Asia-Pacific besides China, are powers sensitive with Chinese behavior. It is important to note that Indian, Chinese and Japanese relations have been "uneasy" since the $19^{\text {th }}$ Century, especially in the case of Japan and China, which have been at war more than once. As to India, which regained independence in 1947, war broke out with China in 1962 with China's invasion of Indian Territory in the Himalayas. India's military suffered a humiliating defeat-6,000 men dead, wounded or taken prisoner (idem). The 1962 war changed the Indian perception about China, causing profound impacts on doctrinal, strategic, operational and tactical issues, which can be seen nowadays.

Since 1949, with the establishment of People's Republic of China (PRC), the country steadily expanded its military control over nearby regions (Tibet, 1959) and strengthened the ability to prevent invasion on the mainland (Gill 2005, 125). China is on its trajectory to be one of the foremost military powers in East Asia-building a capacity to deter Japan and, perhaps in the future, USA itself. Her continuously economic strength and growing nationalism led to an increasing arms build-up and weapons development. Other countries, as India and Japan, see China as a reference in preparing their armed forces to a hypothetical confrontation.

* University La Salle Rio de Janeiro, Rio de Janeiro, RJ, Brazil (wda3059@gmail.com).

** Departament of Political Science, Fluminense Federal University, Niterói, RJ, Brazil (antoniohnriquels@gmail.com) 
This paper will address the following questions: What are the main patterns of security and defense cooperation between Japan and India? Are Japan and India building an "informal alliance"? The objective of the paper is to identify the key elements of a balancing dynamic in relation to China. Using variables such as military spending, military modernization, cooperation arrangements, we will shed light to answers to these questions. The paper is organized as follows. In the first part, covering the theoretical approach, we describe, in the realist tradition, the concepts of balancing, bandwagoning and the sources of threat according to Stephen Walt's definition. The second part is a case study of India and its strategic movements. In the third part, another case study, this time about Japan, highlights its military expenditures, military modernization, as well the changes in military policies, including cooperative agreements with other countries. In the fourth part, actions of India's and Japan's governments are analyzed together in order to shed light to this question: if both countries aim balancing China, is there a "correspondence between their government's policies and their citizen's attitudes"? At the concluding remarks we expose the main findings of the paper.

\section{Theoretical approach}

In the realist tradition, balancing is one of the most used terms. Walt defines balancing as "allying with others against the prevailing threat" $(1987,17)$. Instead of bandwagoning (aligning with the source of danger), states "join alliances to protect themselves from states or coalitions whose superior resources pose a threat" (ibid., 18). Moreover, Walt defines four sources of threat (ibid., 22-6):

- Aggregate power (for example, variables as population size, industrial and military capability, and technological prowess).

- Geographic proximity.

- Offensive power.

- Aggressive intentions.

As to aggregate power, it is very difficult to measure. Nevertheless, items such as population, economy, territory, industrial and military capability, as well as technological level, all converge to the sustainability (or not) of the influence of an specific country in international terms. More, this (rising) influence can easily turn into a perceived threat by its neighbors or even rivals from afar.

Geographic proximity is an important issue due to the fact that "the ability to project power declines with distance" (Walt 1987, loc. cit.). Therefore, perceived threats from a nearby state are usually taken more seriously than from a distant one. In fact, "regional states are more sensitive to threats from other regional powers." (ibid., 158). Also, the number of bordering states (and if these borders can be easily trespassed) is an important issue in molding any state's foreign policy. ${ }^{1}$

1 As an example, the fact of China having 14 neighboring states adds complexity layers to its foreign policy. 
Offensive power is "the ability to threaten the sovereignty or territorial integrity of another state as an acceptable cost" (ibid., 24). Usually this kind of threat triggers a balancing strategy or, if the menacing state is too close and powerful to a quick victory, a bandwagoning option.

Aggressive intentions are the final kind of threat and, in many cases, are determinant to establish a balancing process; bandwagoning with states which are extremely aggressive many times is not a safe option for the weakest states.

Therefore, Walt concludes that the balance of threat framework (where imbalances of threat cause alliances against the most threatening state) subsumes balance of power theory (where imbalances of power cause alliances against the strongest state), "since aggregate power is an important component of threat, but not the only one." (ibid., 264-265).

Paul deepens the meaning of balancing, presenting three types and respective strategies $(2004,13)$ :

Hard balancing - Open arms buildup, formal alliances or both.

Soft balancing - Limited arms buildup. Informal, tacit or ad hoc security understandings among affected states, within or outside international institutions. Preventive strategy.

Asymmetric balancing - Non-state actors and their state sponsors pursue asymmetric strategies.

As already mentioned, buck-passing is another option; in that case, the whole or partial burden of containing the threatening state is passed to a third one (Mearsheimer 2001, 13).

In this study, we will analyze Indian and Japanese behavior towards regional security and if their patterns converge to balancing against a perceived threat (China). We will also analyze what kind of balancing does occur, and if buckpassing is happening.

\section{India}

Since its independence in 1947, India tried to steer its foreign policy towards the need for a peaceful coexistence. The principles of Panchsheel became the cornerstone for its foreign policy, especially after 1954. Prime Minister Jawaharlal Nehru adopted as a foreign policy of state the rejection of the use of force to solve disputes (Hoyt 2007, 22). He changed this orientation after the Himalayan War of 1962 with China and a humiliating defeat. Since then, the new guidelines have been to accumulate power, and new military and diplomatic strategies are based in principles of geopolitics (Kapur 2006, 206). Military expenditure doubled after the war in consequence to the perceived threat of China and the necessity to improve and buy new weapons to counter that country. 
Nevertheless, since independence India has used military power in foreign conflicts and interventions, when needed. It began with the first conflict for Kashmir (1947-1948), the absorption of Hyderabad (1948), the conquest of Goa (1961), the Himalayan War with China (1962), Kutch (1965), the second war in Kashmir (1965), the secession of Bangladesh (1971), intervention in Maldives (1988), peace operation in Sri Lanka (1987-1990) and the Kargil conflict (1999). Regional disputes stimulated the development of nuclear weapons. A nuclear India was, at a first moment, a response to China. When China became a nuclear power in 1964, and its pro-Pakistan policy became more obvious, India reacted developing its own nuclear devices. The dissipation of Nehruvian principles and the belief in China's friendship was replaced by a policy of mistrust and confrontation (Cohen and Dasgupta 2010, 256-265).

The governments in Pakistan — civilian or military—have formulated national defense strategies in terms of a perceived threat by India. Pakistan views India as a hegemonic state and its continuous rise in defense budget as a factor of concern (Sakhuja and Mohanty 2009, 211). Disputes over the Kashmir region remain a major problem for India and Pakistan. In the case of Pakistan, the country has used the issue about the region to gain public support for high military expending and avoiding cuts in its defense budget. The Pakistani military has the total control to formulate defense budget with no peer competition (judiciary or legislative branches) and its implementation (ibid.). Indian strategic contention goals in the region are Pakistan, followed by China, with the possibility of using its military power in the whole region, especially against non-state actors (Bello and Gebrewold 2010,210). Indian military power must be understood in this context of a potential "call" to arms (Cohen and Dasgupta 2010, XII).

During the BJP/Prime Minister Vajpayee's government India accelerated the process of nuclear and military modernization, embracing defense and deterrent as pillars of military strategy (Kapur 2006, 201). India has demonstrated that there is a need to improve its power capabilities to deal with international questions, a very different approach compared to its stance in the first fifteen years of Independence.

United States relations with India had a moment of redefinition when George W. Bush government changed its perception about the region. India has a strategic importance to the United States (clearly defined by Condoleezza Rice): India is an important factor in the strategic calculus of the American government. For the US, considering India in the regional environment is important, leaving the disputes over Kashmir aside, because the country is becoming a Power and this should be taken in account by the American foreign policy (Pant 2008, 21). Washington recent position towards India and Barack Obama's support to the country claims for a permanent seat in the $\mathrm{UNSC}^{2}$ shows clear goals: India is an

2 Obama backs permanent seat for India on Security Council. Available at <http://g1.globo.com/mundo/ noticia/2010/11/obama-indica-apoio-a-assento-para-india-em-conselho-da-onu-1.html>, accessed on $10 / 11 / 2010$. 
important actor to counter China. According to 2010 US Quadrennial Report, the US administration will continue to improve bilateral relations as "inherent recognition" of India's place in the world and the demonstration of strength and potential. The text is very clear about India's impact:

As the economic power, cultural reach, and political influence of India increase, it is assuming a more influential role in global affairs. This growing influence, combined with democratic values it shares with the United States, an open political system, and a commitment to global stability, will present many opportunities for cooperation. India’s military capabilities are rapidly improving through increased defense acquisitions, and they now include long-range maritime surveillance, maritime interdiction and patrolling, air interdiction, and strategic airlift. India has already established its worldwide military influence through counterpiracy, peacekeeping, humanitarian assistance, and disaster relief efforts. As its military capabilities grow, India will contribute to Asia as a net provider of security in Indian Ocean and beyond. (DOD 2010, 60).

Therefore, the mentioned text shows more clearly the shift in the American position towards the Western Pacific and identifies India as a major player, with a greater role in the Indian Ocean and beyond.

As noted above, Indian's commitment to improve its defense dated since 1962. Recently, Indian leadership is supportive in building a strong and modern military in order to: 1) safeguard national security; 2) serve as a deterrent and 3) supply a force to India commensurate with its size and interests. Prime Minister Manmohan Singh assured the Indian military that, if the economy continues to grow at $8 \%$ a year, defense budget will remain at 3\% of the GDP (Sakhuja and Mohanty 2009, 230). Indian Strategy acknowledges the importance of the sea routes. Defense minister George Fernandes stated that "India's area of interest extends from the north of the Arabian Sea to the South China Sea."

India's growing military expenditures (see Table 1) reflect economic prowess and strategic vision to improve the Armed Forces towards state-of-art. The resources spent with PAK-FA program and the choice of $4^{\text {th }}$ generation Rafale fighter to equip Indian Air Force ${ }^{4}$ aim to achieve specific strategic ambitions which take into consideration a record of more than 60 years of belligerence with Pakistan and a Treaty of Peace and Tranquility boundaries signed with China which is not a confidence-building measure completely trustable (as seen in the recent dispute, in April 2013, involving Aksai Chin). The Indian Army is also engaged in questions of internal security responsibilities in Kashmir and Northeast India.

3 India challenges China in South China Sea. In: Asian Times. Available at <http://www.atimes.com/ind-pak/ BD27Df01.html>, accessed on April 27, 2000.

4 France Jet Rafale bags US\$ 20 billion IAF fighter order, India’s 'brief' losing European countries. Available at: http://articles.timesofindia.indiatimes.com/2012-02-01/india/31012278_1_rafale-mmrca-project-frenchair-force 
Table 1. India - military expenditures.

\begin{tabular}{|c|c|c|c|c|c|c|c|c|c|c|c|}
\hline \multicolumn{1}{|c|}{ Year } & 2001 & 2002 & 2003 & 2004 & 2005 & 2006 & 2007 & 2008 & 2009 & 2010 & 2011 \\
\hline \% of GDP & 3 & 2.9 & 2.8 & 2.8 & 2.8 & 2.5 & 2.3 & 2.6 & 2.9 & 2.7 & n.a. \\
\hline US\$ m & 26,741 & 26,658 & 27,253 & 31,657 & 33,690 & 33,962 & 34,374 & 38,987 & 45,903 & 46,086 & 44,282 \\
\hline
\end{tabular}

Obs: n.a. - non-available.

Source: SIPRI (2013). US\$ $\mathrm{m}$ in constant 2010 dollars.

In 2010, India's Minister of External Affairs, Nirupama Rao, noted that:

The rise of China is of course observed with close attention in our region. China's demonstrable economic strength and its growing military capabilities are a matter of fact and we must incorporate such factors into our calculus of the emerging $21^{\text {st }}$ century scenario in the Asia Pacific. This is where a mature and evolving dialogue between India and the United States will be of considerable relevance in clarifying approaches to the regional situation and the policy approaches of roles of our two countries in these new circumstances. ${ }^{5}$

Considering the regional level, India has many still have many concerns about Chinese rise. Flemes and Vaz (2010) point that the achievement of strategic balance has been persistently approached by India sustaining investment in defense capabilities. The modernization of India's armed forces, especially naval and air force, aims to support its status of emerging power and preserve its supremacy in the Indian Ocean (Dördrechter 2010). On the other hand, at the global level, India tends to make alignments with other countries seeking long terms arrangements as BRICs formation (with Brazil, Russia, China and South Africa as partners) (Scott 2011, 278). As has been noted by Ollapally, in the new global system each country feels it is necessary to diversify its relationships. In the case of BRICS, India has a long tradition of ties with Russia, mainly due to the purchase of arms. Nowadays, the logic of international system makes partnerships and coalitions more tactical in nature offering a case to case analysis $(2009,208)$. Russia is also important to India because of its energy resources. Sustainable Indian economic growth is important to maintain the economy in a fast track. Brazil does not have the same strategic importance to India as Russia and China.

It is still an open question, in diplomatic terms, about the BRICS real capacity to constitute a homogeneous bloc capable of a significant influence in the process of building a new international order. ${ }^{6}$ As to India and China, Miller (2013) points the problems that India has to face in order to counter an ambitious China in the near future, stressing that countries which aspire to great-power status usually look

5 Ministry of External Affairs, India. "The United States and India: Chartering the Future Course", Speech in India Initiative of the Centre for New and American Security and the ASPEN Institute India. Available at: Scott (2011). India’s Relations with the USA. In: Scott, David. Handbook of India’s International Relations. London: Routledge.

6 Almeida $(2010,136)$ 
beyond tactical challenges. According to the author, India did not yet develop a long term strategy for its growing power, in a sharp contrast with China, which has clear strategies about its power. Furthermore, the international community shows some signs towards empowering India, as the support for a permanent seat at the United Nations Security Council and Washington's efforts so that New Delhi would operate as a counterweight to China. As we demonstrated in this part of the paper, Indian issues have a big focus on its regional relations. Efforts are being made to attenuate these questions. New relations and interests on higher levels may shape Indian preferences.

Japan

After the defeat in World War II, Japan faced two basic problems: how to adapt itself to a world liberal order steered by the US and, shortly after, the impact of the Cold War. At Yalta, American strategists had foreseen two spheres of influence, the US over Japan and Soviet Union in Northeast Asia. China would constitute a "grey area," balancing the two superpowers (Pyle 2007, 217). With this in mind, an American-imposed Constitution was given to Japan which stated that, besides renouncing "war as an instrument of the State," the country would repudiate the "maintenance of military forces." (Samuels 2007).

With the perception that CCP (Chinese Communist Party) would win the Chinese Civil War, the US began to give another focus to Japan. In 1948, George Kennan warned that Japan was in danger of falling in Soviet sphere, if the Occupation did not foster the Japanese to "a position where they would be better able to shoulder the burden of independence" (Pyle 2007, 221). In fact, in few years Japan was to be transformed "from bitter wartime enemy to the lynchpin, the key ally, in the new US security structure in Cold War Asia" (ibid., 225).

But Japan did not rearm itself. Branding the argument of Article 9 of the Constitution, Japanese government stated that Japan could not take part in any foreign conflict. Withstanding several demands by the US, in 1954 Japan established the Japan Defense Agency, with self-defense forces of 152 thousand men (ibid., 229-236). Therefore, a "minimum force" (which could not be sent $\operatorname{abroad}^{7}$ ) was institutionalized, with the basic goal of protecting the country.

Almost twenty years later, Japan formulated the policy of the "Three Principles of Army Exports," which banned those exports to Communist countries, to countries blacklisted by UN embargoes or to countries involved or likely to be involved in armed conflicts. Afterwards, the ban was extended to all countries (Pyle 2007, 253-254). At the same time, the National Defense Program Outline, in 1976, formalized the 1 percent of GNP ceiling as to military expenditures. ${ }^{8}$

7 For example, while South Korea sent more than 300 thousand men to the Vietnam War, Japan sent none, according to Pyle $(2007,254)$.

8 Since the 1960s the ceiling had been informally applied, according to Pyle $(2007,254)$. 
During the Cold War, Yoshida Doctrine came to be seen as very useful, since Japan recovered from the defeat in WWII and became one of the biggest economic powers, while been protected by the US (the so-called "nuclear umbrella"). But, with the end of the Cold War, the premises for that strategy were shaken. ${ }^{9}$

The Gulf War, in 1991, also highlighted some important issues; first, the need to intense modernization, as US victory showed the state-of-art technology in military affairs. Second, although there was an intense debate about "collective security," the Cabinet Legislation Bureau stuck to its interpretation that "dispatch of SDF troops to join the coalition in any form was constitutionally prohibited." Even the sending of a medical team of hundred specialists came to nothing, since only twenty volunteers stood up to the call and soon returned home (Pyle 2007, 290-291). In the end, Japan's contribution came to US\$ 13 billion, which only worsened its position among the other countries in the coalition; Japan's initiative came to be criticized and labeled as "checkbook diplomacy" (ibid., loc. cit.).

After the Gulf War, the debate about military forces in Japan deepened. The United Nations Peacekeeping Operations Cooperation Bill, approved in 1992, allowed sending SDF troops abroad to give logistical and humanitarian support for UN missions; the first one consisted of 700 personnel going to Cambodia.

Therefore, the post-Cold War brought new challenges to Japan and clearly Yoshida Doctrine had to be somewhat revised. Changes were slow, but seen in a wider perspective, significant. The most important threats were "a) a rising China; b) a miscreant regime in North Korea; c) the possibility of abandonment by the United States; d) relative decline of the Japanese economy." Samuels points that Japan has responded to each threat with an adaptation of its strategy and, more important, "each of these threats have been used to justify the modernization of Japan's military” (Samuels 2007, 4-5).

For example, the launching of a North Korean three-stage ballistic missile over Japan, in 1998, prompted Japanese developing of its own surveillance satellite and BMD (ballistic missile defense), but with interoperability with US forces (ibid., 104-105).

The strengthening of the operational capability of the Japanese Coast Guard is also striking. In 2005, it had a fleet with as much as $65 \%$ of the total tonnage of China's surface fleet (Samuels 2007, 70). Since the JCG is not one of the Self Defense Forces, its expenditures are not within the budget ceiling of $1 \%$ of GNP, usually applied to military expenditures.

The creation of the Ministry of Defense, in January 2007, elevating the prior Japan Defense Agency and coordinating all three Self Defense forces, represented the institutionalization of a new approach to security. With that, Japan has had talks with several countries in order to foster more solid ties as to regional security,

9 In fact, even Yoshida Doctrine was criticized, during the Cold War. For an overview of the Japanese political debate over the issue, see Samuels (2007, 38-59) 
besides the US, as Australia, South Korea, India, Indonesia and Vietnam (Nids 2012, 259).

But Japan's biggest concern is China's constant growth, not only for historical reasons, since both countries have still to erase the traumas of their last mutual conflict, but also for maritime disputes that constantly erupt, regarding some islands and reefs. Those places are not important per se, but the sovereignty over them grants the respective country the rights over the surrounding Exclusive Economic Zone.

In 1995, the National Defense Program Outline (NDPO) did not mention China explicitly, although pointed to nuclear arsenals in neighboring states. But National Program Defense Guidelines (NPDG) in 2004 was "the first national security document to openly identify a potential threat from PRC, $[\ldots]$ that was modernizing its forces and expanding its range at sea"(Samuels 2007, 69). There was a shift in military focus from Hokkaido and northern Honshu southward, "where assets could be more easily deployed against perceived Chinese threats" (ibid., 65, our emphasis).

As the latest Japan White Paper points, in its Introduction, "The security environment surrounding Japan is becoming increasingly harsh, due to challenges such as acts of provocations, including North Korea's launching of the missile, which it called "Satellite" and the nuclear test, and the rapid expansion and intensification of activities by China in the waters and airspace around Japan, including intrusion into Japanese territorial waters and airspace" (Mod 2013). When analyzing specific threats, China is highlighted, with Japan stressing the several conflicting events over territorial waters which Japan claims as its own.

As already mentioned, Japan cannot be totally sure about US intentions. Nevertheless, the strategic focus in Asia ("Asian pivot"), as announced by President Obama, is a reassurance of both countries' alliance (since Japan is fundamental to its success), at least in the near and medium term, as well as the strengthening of other partners, as Australia and India.

In terms of military expenditures, albeit the ceiling of $1 \%$ of the GNP, Japan's position in world ranking is sixth, after the US, China, Russia, France and United Kingdom, but not very distant from the last two (Sipri 2013). As it can be seen comparing Tables 1 and 2, even with the ceiling of 1\% Japan's military expenditures are higher than India's (which comprise almost 3\% of the GDP).

Table 2. Japan - military expenditures.

\begin{tabular}{|c|c|c|c|c|c|c|c|c|c|c|c|}
\hline Year & 2001 & 2002 & 2003 & 2004 & 2005 & 2006 & 2007 & 2008 & 2009 & 2010 & 2011 \\
\hline \% of GDP & 1 & 1 & 1 & 1 & 1 & 1 & 0.9 & 0.9 & 1 & 1 & 1 \\
\hline US\$ mil & 55,376 & 55,938 & 56,053 & 55,541 & 55,330 & 54,637 & 53,885 & 53,159 & 54,339 & 54,641 & 54,529 \\
\hline
\end{tabular}

Source: SIPRI (2013). US\$ mil in constant 2010 dollars. 


\section{India/Japan}

In the Cold War, and even a decade further, diplomatic relations between India and Japan were, according to Laurence, "cordial, as might be expected from two democracies." $(2007,195)$.

In 2000, both countries decided the establishment of "Global Partnership between Japan and India" (Mofa 2012a). Among other broad issues, Japan and India "talked about institutionalizing a dialogue between the ministries of defense and foreign affairs for coordinated actions on security and foreign policy related issues, such as the security of sea-lanes, joint naval exercises to combat piracy and disaster management."(Baruah 2010). Such an alliance, in an Indian perspective, could "help offset the deleterious effects for New Delhi of the long-standing Sino-Pakistan nexus." (Chelaney 2010, 205). As to Japan, it diversified her security partners, therefore avoiding an excessive dependency on the US, as well as enhancing a more assertive posture as a "normal" power.

A year later, in July, the first meetings of the Japan-India Security Dialogue and the Japan-India Military-Military Consultation took place. In December of the same year, Prime Ministers Junichiro Koizumi and Vajpayee signed the IndiaJapan Joint Declaration, which highlighted the pledge to cooperation in many issues, including the safety and security of maritime traffic and fostering defense exchange (Baruah 2010).:

The next inflexion in both countries' relationship came in 2005, after many incidents in China against Japan's efforts to secure a permanent seat in UN Security Council (Chelaney 2010, 204; Sudo 2007, 51-52; Kokubun 2007, 137-142). In April, both Prime-Ministers (Koizumi and Singh) produced "the joint statement "Japan-India Partnership in a New Asian Era: Strategic Orientation of Japan-India Global Partnership," as well as an Action Plan called the "Eightfold Initiative for Strengthening Japan-India Global Partnership.” The action plan emphasized the security cooperation with: "a) further developing dialogues and exchanges, including through full utilization of existing consultation forums; b) strengthening service-to-service exchanges between defense establishments of the two countries; c) working to ensure the safety and security of maritime traffic through joint exercises against piracy and the annual Japan Coast Guard-Indian Coast Guard talks; and d) building up cooperation between the Maritime Self Defense Force (MSDF) and the Indian Navy in recognition of the importance of maritime security."(Baruah 2010).

In terms of a wider strategy, the signing of the Indian-Japanese "Global Partnership" coincided with the nuclear deal between India and the US, unveiled in July 2005 (Chelaney 2010, 206-207) and with Japan's effort to include India as a member of EAS (East Asian Summit). ${ }^{10}$ According to Simon, "Other ASEAN

10 EAS original members were: all of ASEAN countries plus China, South Korea, Japan, India, Australia and New Zealand. Russia and the US have been added, since then. 
members plus Japan, however, fearing China's possible domination, pressed for invitations to Australia, New Zealand and India" (2008, 209).

In 2007, "a joint naval exercise was conducted by Japan, India, Australia, Singapore and the United States in September 2007" (Emmott 2008, 133). "Malabar" exercises, usually with Indian and American forces, were expanded in terms of other participating countries.

Aside from the Japanese participation in Malabar 2009, this time in the eastern side of Okinawa, in April, the idea of a Defense Action Plan (DAP) was conceived, including a "2 plus 2" dialogue framework at senior official level of external affairs and defense ministries and "an annual strategic dialogue at the foreign minister level" (Baruah 2010). The so-called " $2+2$ " framework, in Japanese foreign policy terms, means an extremely high level of consultation and strategic stature.

In 2011, due to the Fukushima nuclear accident, Japan did not take part in Malabar naval exercise. In November, India's Defense Minister met with Japanese Defense Minister and they decided to "to carry out bilateral exercise between the Japan Maritime Self-Defense Force and the Indian Navy."

In January 2012, both Coast Guards conducted exercises on anti-piracy, search and rescue missions, etc., as has been happening since $2000 .{ }^{11}$ There was no official statement about Japan missing Malabar 2012; two seem to be the basic reasons. One is the emphasis in bilateral naval exercises, ${ }^{12}$ as put forth in the 2011 Summit, and the other the full alert due to North Korea's satellite launching, mobilizing a sizeable part of Japan's maritime SDF and Coast Guard.

In April, India held the sixth India-Japan Foreign Ministers' Strategic Dialogue. One of the issues highlighted was that "cooperation between Japan and India in the field of maritime security had been steadily deepened, referring to joint exercises between the Japan Coast Guard and the Indian Coast Guard, bilateral cooperation on anti-piracy activities, as well as a joint naval exercise between Maritime Self-Defense Force and Indian Navy scheduled to be held in that same year." (Mofa 2012b). ${ }^{13}$

Also, "regarding the joint industrial activities on rare earth materials, the two Ministers shared the view that they should work toward an early realization of the activities." It should be noted that, amid a Senkaku/Diaoyutai incident in 2010, Chinese reaction included the embargo in rare earth materials export to Japan. Therefore, Japanese incentive to Indian rare earth production is not a random choice. The emphasis on strengthening relations between Indian Navy and Japan MSDF, as well as the cooperation concerning rare earth materials, was reinforced in the Prime Ministers' meeting in November 2012.

India and Japan are also increasing their ties in the defense industry. Japan has relaxed its arms exports policy (Murayama 2011); the Indian Navy is evaluating

11 Ibid.

12 As already mentioned, Malabar exercise is comprised basically of Indian and US navies participation.

13 JIMEX 12 (Japan India Maritime Exercises) came to happen in June 2012. 
the acquisition of Shinmaywa US-2 amphibious aircraft; "a short take-off and landing (STOL) amphibious aircraft that can take off from either land or from water with 18 tons of load. Its range of 4,700 kilometers reaches across vast tracts of ocean, performing multiple tasks: humanitarian aid, disaster relief, search and rescue, as well as military logistical activities." (Shukla 2012). In Prime Minister Singh's visit to Japan, in May 2013, both governments decided to improve joint maritime exercises and the establishment of a Joint Working Group on the US-2 amphibian aircraft (Mofa 2013a; Kesavan 2013).

Therefore, Indian-Japanese ties in the security field have been deepened significantly, since 2000. According to Hemant Kumar Singh, a former India's ambassador to Japan, "there are three drivers of Tokyo's decisive turn towards New Delhi: India's economic rise; India's growing ties with the US; and Japan's fear of a rising China" (Shukla 2012). Those three drivers have reinforced each other, along the years, exemplified by the five meetings of the "India-Japan-United States trilateral dialogue," with issues such as "as maritime security and regional situations," since December 2011 (Mofa 2013b).

A last point to be analyzed about India and Japan strategic movement towards China would be the following: if both countries aim balancing China, is there a "correspondence between their government's policies and their citizen's attitudes"? We will use a similar approach to Chang (2010), in analyzing if East Asian countries were balancing against China.

Not surprisingly, due to historical reasons (including Japanese expansion in Chinese territory after 1894 Sino-Japanese War and way into $20^{\text {th }}$ Century's first half), continuous rivalry and especially territorial disputes (for example, Senkaku/ Diaoyutai islands), Japan views about China have not been positive, in average, according to the world poll sponsored by $\mathrm{BBC}$ and conducted by the international polling firm GlobeScan, together with the Program on International Policy Attitudes (PIPA) at the University of Maryland. In fact, the net result (difference between mainly positive and mainly negative views) is persistently negative, since 2008 (year when Japanese began being interviewed), with an average of $-39 \% .^{14}$

As to India, according to the poll, the views about China have been worsening steadily, going from a net result of +46 in 2005 to -27 in 2011 (Table 3). The reduction of the negative views in 2012, which nevertheless was insufficient to turn the net result to positive, was due to the Chinese support among the BRICS group to an Indian (and Brazilian and South African) permanent seat in the UNSC. When the 2013 views come to light, the impact of the military incident at Aksai Chin in April should be taken into consideration, with the possibility of a new worsening of Indian perception about China. So, economic and geopolitical rivalry (for example, fighting for the bigger influence in Myanmar), territorial disputes

14 In Pew Research Center (2013), China is seen in unfavorable way by $95 \%$ of the Japanese, while $5 \%$ see her in a favorable way, according to a 2013 poll. 
(as in the cases of Aksai Chin and Arunachal Pradesh), political issues like Tibet, etc., all summed up to radically change the average perception of China in India, since $2005 .^{15}$

Table 3. India's and Japan's views on China, 2005-2011 (percentage of people interviewed).

\begin{tabular}{|l|c|c|c|c|c|c|c|c|}
\hline \multicolumn{1}{|c|}{ Year } & 2005 & 2006 & 2007 & 2008 & 2009 & 2010 & 2011 & 2012 \\
\hline India & & & & & & & & \\
\hline Mainly positive & 66 & 44 & 35 & 22 & 30 & 30 & 25 & 30 \\
\hline Mainly negative & 20 & 15 & 22 & 18 & 24 & 38 & 52 & 31 \\
\hline Net result & +46 & +29 & +13 & +4 & +6 & -8 & -27 & -1 \\
\hline Japan & & & & & & & & \\
\hline Mainly positive & n.a. & n.a. & n.a. & 12 & 8 & 18 & 12 & 10 \\
\hline Mainly negative & n.a. & n.a. & n.a. & 59 & 59 & 38 & 52 & 50 \\
\hline Net result & n.a. & n.a. & n.a. & -47 & -51 & -20 & -40 & -40 \\
\hline
\end{tabular}

Note: n.a. = non-available. Specific percentages linked to answers as "depends," "neutral” or "don't know" or no answer at all were not released.

Source: Elaborated on data from BBC (2013).

The previous remarks show that a balancing strategy by India and Japan finds support in both populations.

\section{Conclusion}

In the first part of our paper, we described the basic theoretical approach which would be applied to the analysis. In the second, strategic movements of India were considered. Pakistan is still a major concern for India's foreign policy but China, as a rising power, poses many security risks for the country. India's military expenditure continues steady while Chinese economic growth allows that more resources keep up flowing for China's military modernization. China's rise demanded a more focused strategy to counter any further problem that India may face. In the third part we described Japan's perception of China. Despite the Japanese constitution imposing serious restrictions to the country forces, other measures such as improving the coast guard are a clear evidence that Japan will use further measures to ensure a defense capability ready to face strategic problems in the Asia-Pacific region. In the fourth part we described the convergence of interests among India and Japan. It is important to emphasize the several United States

15 This big drop in the net result for China coincides with a great surge upward in the net result for Indian views toward United States, going from -6 in 2008 to +17 in 2012. Incidentally, the same trend can be found in Japan views toward United States, going from -17 in 2008 to +14 in 2012. See BBC (2012) for further details. 
movements towards India and China. The recent support to an Indian permanent seat in the United Nations Security Council, by Obama's administration, it is a view of a rising India and its growing importance in the region. Therefore, not allowing a growing asymmetry of power between India and China became part of the American foreign policy.

Our work has also shown that Japan and India have been strengthening their security dialogue, since 2000 , especially after 2005 . Does this process fit into Walt's analytical framework of balance of threats?

As to Walt's geographic, rising power and offensive power issues, all of them are clearly present in India's and Japan's relationship with China (and are not subjective). And the fourth one, aggressive intentions? China does not position itself as an aggressive power. But, as Mearsheimer (2010, 383) points,

Unfortunately, states can never be certain about each other's intentions. They cannot know with a high degree of certainty whether they are dealing with a revisionist state or a status quo power. [...] But even if one could determine China's intentions today, there is no way to know what they will be in the future. After all, it is impossible to identify who will be running the foreign policy of any country 5 or 10 years from now, much less whether they will have aggressive intentions. It cannot be emphasized enough that we face radical uncertainty when it comes to determining the future intentions of any country, China included.

Even today, Chinese reactions to some incidents, as the aforementioned one at the Senkaku/Diaoyutai islands, in September 2010, or denying visas to Indian citizens who were born in Arunachal Pradesh (a disputed area with India), turn Indian and Japanese perceptions cloudy as to a potential threat presented by China.

And, since one of the issues which can trigger an alliance, according to Walt, is a perceived threat, Indian and Japanese responses have been in the direction of finding a common ground against that threat.

Nevertheless, it should be noted that their relationship would represent a "soft balancing" approach, or as pointed by Paul $(2013,13)$, "Limited arms buildup; Informal, tacit or ad hoc security understandings among affected states, within or outside international institutions. Preventive strategy."

In fact, India is also a partner with China in some groups, like RIC and BRICS, and uses that partnership to enhance their diplomatic position in the world, as gaining support to a permanent seat in the UN Security Council. ${ }^{16}$ But the fact still remains that India's defense policy still puts China as one of the major worries, alongside Pakistan.

In tandem, Japan has sought to establish firmer ties with China, in economic terms (for example, the efforts towards the Trilateral Summit with South Korea,

16 According to Amorim and Coelho (2012), "BRICS seem much more a 'Resonance Chamber' for revisionism." 
China and Japan, which has already produced an Investment Treaty among the three countries, as well as the establishment of a formal Secretariat and talks about a Free Trade Zone). Nevertheless, Japan's defense policy also puts China as one of the main sources of threat, in security terms.

That approach by both countries is also stimulated by the US, which also tends to "contain" China's rise. The importance of Japan to balance against China had already been envisioned by Spykman in 1942, even at the apex of World War II $(2007,468-470)$. Therefore, it is not fortuitous at all that the relationship between India and Japan has taken a boost since 2005, when US and India began sharing common interests in terms of a new strategic partnership. ${ }^{17}$

As Japan seems to overcome most of the economic problems derived from the Fukushima incident, a more assertive position in security issues has been highlighted by Prime Minister Shinzo Abe. On the other hand, India's growth continues to be one of the biggest in the emerging economies. As we exposed in this paper, Japan and India are "getting closer" because both have a convergent focus, as to security: China's rise. Yet it should be stressed that the Asia-Pacific region is not in a full "security dilemma" which would drive the region through a dangerous (and out of control) arms race. China continues to modernize its military and, as noted above, Japan and India are in a soft balancing strategy towards China. Chinese intentions are difficult to preview but it is a fact that her strategic movements became reference for other countries with spin-offs as the building of "informal alliances" like Japan and India aligning in security affairs. The $21^{\text {st }}$ century, especially in the Asia-Pacific region, will observe a steady disparity of power between China and the other countries, if recent trends continue. Allying with others seems to be one of the paths to be pursued in order to fulfill the gap created by China's ascension.

\section{Bibliographic references}

ALMEIDA, Paulo Roberto (2010). O Bric e a substituição de hegemonias: um exercício analítico (perspectiva histórico-diplomática sobre a emergência de um novo cenário global). In: BAUMANN, R., Ed. O Brasil e os demais BRICs: Comércio e Política. Brasília: IPEA.

AMORIM, Wellington \& COELHO, Carlos Frederico (2012). Useful Tool or Shallow Acronym? Foreign Policy Coordination Amongst BRICS countries. Paper presented at ISA Annual Convention, San Diego.

BARUAH, Pranmita (2010). Changing Contours of the Japan-India Defense Relations. Available at: http://globalpolitician.com/print.asp?id=6267. Retrieved in April 30, 2012.

BBC (2013). World Service Country Rating Poll. Available at: http://www.worldpublicopinion. org/pipa/articles/views_on_countriesregions_bt/717.php?lb=btvoc\&pnt=717\&nid=\&id= Retrieved in 11/08/2013.

17 This US incentive could be interpreted as a sort of minor "buck-passing." 
BELLO, Valeria \& GEBREWOLD, Belachew, Ed. (2010). A Global Security Triangle: European, African and Asian Interaction. London: Routledge.

BLACK, Jeremy (2005). Introduction to Global Military History: 1775 to the present day. New York: Routledge.

BUSH, Richard C. (2010). The Perils of Proximity: China-Japan Security Relations. Washington: Brookings Institution Press.

CHAN, Steve (2010). An odd thing happened on the way to balancing. International Studies Review, vol. 12, issue 3.

CHELLANEY, Brahma (2010). Asian Juggernaut: the rise of India, China and Japan. New York: Harper.

COHEN, Stephen P.; DASGUPTA, Sunil (2010). Arming without aiming: India's Military Modernization. Washington: Brookings Institution Press.

DOD (2010). Quadriennal Defense Review Report. Available at: http://www.defense.gov/qdr/ images/QDR_as_of_12Feb10_1000.pdf. Retrieved in: May 6, 2013.

DÖRDRECHTER, Stefan et al. (2010), Aufrüstung neuer Mächte: China, Indien, Brasilien und Iran, GIGAFocus Global, 1, Hamburg: GIGA German Institute of Global and Area Studies.

EMMOTT, Bill (2008). Rivals: how the power struggle between China, India and Japan will shape our next decade. Orlando: Harcourt.

FLEMES, Daniel; VAZ, Alcides Costa (2011). Security Policies of India, Brazil and South Africa - Regional Security Contexts as Constraints for a Common Agenda. GIGA Working Papers n¹60. Hamburg: German Institute of Global Area Studies.

FRAVEL, M. Taylor (2008). Strong borders, secure nation: cooperation and conflict in China's territorial dispute. Princeton: Princeton University Press.

GILL, Bates (2004). China as a regional military power. In: BUZAN, Barry; FOOT, Rosemary, Ed. Does China matter? A Reassessment. London: Routledge.

GOSWAMI, Namrata (2012). China ups the ante in Arunachal Pradesh. IDSA Comment. Available at: http:/www.idsa.in/idsacomments/ChinaupstheanteinArunachalPradesh_ NamrataGoswami_170112. Retrieved in March 5, 2012.

HOYT, Timothy D. (2007). Military Industry and Regional Defense Policy: India, Iraq, and Israel. New York: Routledge.

KAPUR, Ashok (2006). India - From Regional to World Power. New York: Routledge.

KESAVAN, K.V. (2013). The imperial impetus behind Indo-Japanese relations. East Asia Forum. Available at: http://www.eastasiaforum.org/2013/10/05/the-imperial-impetus-behindindo-japanese-relations/. Retrieved in: 11/05/2013.

KOKUBUN, Ryosei (2007). Changing Japanese Strategic Thinking Toward China. In: ROZMAN, Gilbert, TOGO, Kazuhiko \& FERGUSON, Joseph S., Ed. Japanese Strategic Thought toward Asia. New York: Palgrave MacMillan.

LAURENCE, Henry (2007). Japan's proactive foreign policy and the rise of the BRICs. Asian Perspective, vol. 31, no 4 Available at: http://www.asianperspective.org/articles/v31n4-a.pdf. Retrieved in February 13, 2012.

MEARSHEIMER, John J. (2001). The Tragedy of Great Power Politics. Norton: New York. 
(2010). The Gathering Storm: China's Challenge to US Power in Asia. The Chinese Journal of International Politics, Vol. 3.

MILLER, Manjari Chaterjee (2013). India’s Feeble Foreign Policy: A would-be great power resists its own rise. Foreign Affairs, May/June 2013. Available at: http://www.foreignaffairs.com/ articles/139098/manjari-chatterjee-miller/indias-feeble-foreign-policy Retrieved in 11/08/2013.

MOD (2010). SUMMARY OF NATIONAL DEFENSE PROGRAM GUIDELINES for FY 2011 and beyond. Available at: <http://www.mod.go.jp/e/d_act/d_policy/pdf/summaryFY2011. pdf>, accessed on May 20, 2012.

(2013). DEFENSE OF JAPAN 2013 (Annual White Paper). Available at: http://www. mod.go.jp/e/publ/w_paper/2013.html. Retrieved in 11/08/2013.

MOFA (2012a). Japan-India Relations. Available at <http://www.mofa.go.jp/region/asia-paci/ india/>, accessed on May 4, 2012.

. (2012b). Visit to India by Minister for Foreign Affairs Koichiro Gemba. Available at <http://www.mofa.go.jp/region/asia-paci/india/meeting1204_fm.html>, accessed on May $10,2012$.

. (2012c). Japan-India Summit Meeting. Available at <http://www.mofa.go.jp/announce/ jfpu/2012/11/1120-01.html>, accessed on May 5, 2013.

. (2013a). Visit to Japan by Dr. Manmohan Singh, Prime Minister of India and Mrs. Gursharan Kaur. Available at: http://www.mofa.go.jp/region/page6e_000071.html. Retrieved in: $11 / 08 / 2013$.

. (2013b). The $5^{\text {th }}$ meeting of the trilateral dialogue. Available at: http://www.mofa. go.jp/press/release/press4e_000076.html. Retrieved in: 11/14/2013.

MURAYAMA, Yuzo (2011). A review of the three principles on arms exports. Available at: http://nippon.com/en/currents/d00016/. Retrieved in 05/04/2012.

NIDS (2012). East Asian Strategic Review. Available at: http://www.nids.go.jp/english/ publication/east-asian/e2012.html. Retrieved in 05/12/2012.

OLLAPALLY, Deepa (2009). India and Russia: Renewing the relationship. In: PANT, Harsh, Ed. Indian Foreign Policy in a Unipolar World. New Delhi: Routledge.

PANT, Harsh V. (2008). Contemporary debates in Indian foreign and security policy: India Negotiates Its Rise in the International System. Hampshire: Palgrave Macmillan.

PAUL, T.V. (2004). Introduction: the enduring axioms of balance od power theory and their contemporary relevance. In: PAUL, T.V., WIRTZ, James. J. \& FORTMANN, Michel, Ed. Balance of Power: Theory and Practice in the $21^{\text {st }}$ Century. Stanford: Stanford University Press.

PEW RESEARCH CENTER (2013). Global Attitudes Project. Available at: http://www.pewglobal. org/database/indicator/1/country/100/response/Unfavorable/. Retrieved in 11/09/2013.

PYLE, Kenneth B. (2007). Japan rising: the resurgence of Japanese power and purpose. New York: Public Affairs.

SAKHUJA, Vijay; MOHANTY, Deba R. (2009). Globalization and defence economy in South Asia: Two views. In: TILL, G; CHEW, E.; HO, JOSHUA, Ed. Globalization and Defence in the Asia-Pacific: Arms across Asia. New York: Routledge.

SAMUELS, Richard J. (2007) Securing Japan: Tokyo's grand strategy and the future of East Asia. Ithaca: Cornell University Press. 
SCOTT, David (2011). India's relations with the USA. In: SCOTT, David, (Ed.) Handbook of India's International Relations. London: Routledge.

SHUKLA, Aijai (2012) India, Japan to talk on cooperation in Asia-Pacific. Available at: http://ajaishukla.blogspot.com.br/2012/04/india-japan-to-talk-on-cooperation-in.html. Retrieved in 04/30/2012.

SIMON, Sheldon (2008). ASEAN and the New Regional Multilateralism: the Long and Bumpy Road to Community. In: SHAMBAUGH, David \& YAHUDA, Michael, Ed. International Relations of Asia. Plymouth: Rowan and Littlefield.

SIPRI (2013). The SIPRI Military expenditure database. Available at: http://milexdata.sipri. org/. Retrieved in 11/08/2013.

SPYKMAN, Nicholas J. (2007). America's strategy in World Politics. New York: Harcourt, Brace and Co.

SUDO, Sueo (2007) It takes two to tango. In: HSIUNG, James C. (ed.) China and Japan at odds: deciphering the perpetual conflict. New York: Palgrave MacMillan.

WALT, Stephen (1987). The origins of alliances. Cornell: Cornell University Press.

Submitted November 15, 2013

Accepted February 5, 2014

\begin{abstract}
What are Indian and Japanese reactions to China's rise in economic, political and military terms? According to realist tradition, their option would be between balancing and bandwagoning. Applying Stephen Walt's balance of threats approach, this work aims to analyze Indian and Japan responses to an increasingly powerful China; its conclusions point to an evolving relationship between India and Japan, in military terms, especially after 2005.
\end{abstract}

Keywords: China; India; Japan.

\title{
Resumo
}

Quais são as reações indianas e japonesas a ascensão da China no âmbito econômico, político e militar? De acordo com a tradição realista suas opções seriam entre balancing e bandwagoning. Aplicando a abordagem do equilíbrio pela ameaça de Stephen Walts, este trabalho visa analisar as respostas da Índia e do Japão diante de uma crescente e poderosa China; suas conclusões apontam para uma evolução do relacionamento entre Índia e Japão, em termos militares, especialmente após 2005.

Palavras-chave: China; Índia; Japão. 